\title{
Intraspecific variation of growth and adaptive traits in North American oak species
}

\author{
HB Kriebel \\ School of Natural Resources, Division of Forestry, The Ohio State University, \\ Wooster, $\mathrm{OH}$ 44691-4096, USA
}

\begin{abstract}
Summary - Variation of growth and adaptive traits has been identified in Quercus rubra L, which has recognizable geographic patterns in replicated test plantations in the central and western parts of the species range. Traits varying geographically include growth rate, drought resistance, cold resistance, time of flushing and leaf senescence. Patterns may differ in tests in southern regions. In Quercus falcata Michx, coastal plain sources are superior to others in both central Mississippi and western South Carolina. In 3 partial-range Quercus pagoda Raf tests, local or regional sources outrank others in growth and adaptability. Both of these species vary widely in cold hardiness. Local trees of Quercus alba $L$ are above the average height of all Indiana trees at age $5 \mathrm{yr}$ in southern Indiana, but local trees of Quercus macrocarpa Michx in Nebraska are not as fast-growing as trees from seed sources $160 \mathrm{~km}$ south. Range-wide patterns remain undefined in both of these species. Among western provenances of Quercus nigra $L$ in Louisiana, flushing is latest in trees of the northernmost origins. Only fragmentary information is available on variation of growth and adaptive traits in 7 other oaks, all eastern North American species.
\end{abstract}

\section{Quercus / oaks / variation / growth / adaptive traits / hardiness}

Résumé - Variabilité intraspécifique des caractères d'adaptation et de croissance chez les espèces d'Amérique du Nord. La variabilité des caractères de croissance et d'adaptation a été étudiée chez Quercus rubra $L$; des gradients de variation ont clairement pu être établis chez cette espèce au vu des résultats obtenus dans des plantations installées dans la partie centrale et occidentale de l'aire naturelle. Les caractères, dont la variabilité suit un gradient géographique, sont : le taux de croissance, la résistance à la sécheresse et au froid, la date de débourrement et la sénescence des feuilles. Ces gradients peuvent être différents dans les plantations installées dans la partie méridionale de l'aire. En ce qui concerne Q falcata Michx, les origines des plaines côtières sont supérieures aux autres dans la partie centrale du Mississippi, et la partie occidentale de la Caroline du Sud. Dans 3 plantations de Q pagoda Raf ne comprenant qu'un échantillon partiel de provenances, les populations locales étaient nettement supérieures aux autres pour la croissance et les caractères d'adaptation. Les origines locales de $\mathrm{Q}$ alba $L$ ont une meilleure croissance que les autres dans le sud de l'Indiana (à 5 ans); alors que chez Q macrocarpa Michx dans le Nebraska, les origines locales sont moins vigoureuses que celles originaires de $160 \mathrm{~km}$ au sud. Les gradients de variation au niveau de l'ensemble de l'aire naturelle n'ont pas encore été étudiés pour ces 2 espèces. 
En Louisiane, chez $\mathrm{Q}$ nigra $L$, le débourrement est plus tardif chez les provenances les plus nordiques. Des données fragmentaires sur la variabilité des caractères de croissance et d'adaptation existent pour 7 autres espèces, toutes issues de l'est des Etats-Unis.

\section{Quercus / chênes / variabilité / croissance / adaptation / résistance}

\section{INTRODUCTION}

North America has about 58 species of oaks (genus Quercus) of tree size, of which about 20 are considered important in forest management (Fowells, 1965). Many of the North American oaks are distributed over a wide range of latitude and longitude and over several of the plant hardiness zones used as guidelines in horticulture (fig 1, table 1). Some are extremely wide-ranging. $Q$ macrocarpa Michx, one of the most widely-distributed species, occurs from 28-53 ${ }^{\circ} \mathrm{N}$ latitude and 66-105 ${ }^{\circ} \mathrm{W}$ longitude. Therefore, adaptive traits, and perhaps growth rate as well, could be

Table I. Plant hardiness zones and approximate extremes of average minimum winter temperature within the natural distribution of 8 North American oaks (US Dep Agric, 1960; Fowells, 1965).

$\begin{array}{cc}\text { Species } & \begin{array}{c}\text { Plant } \\ \text { hardiness }\end{array} \\ \text { zones } & \text { minimum of average annual } \\ & \left({ }^{\circ} \mathrm{C}\right)\end{array}$

\begin{tabular}{lll} 
Q macrocarpa & $2-9$ & -43 to -4 \\
Q rubra & $2-8$ & -42 to -7 \\
Q alba & $4-9$ & -34 to -5 \\
Q velutina & $4-9$ & -31 to -6 \\
Q shumardii & $5-9$ & -26 to -3 \\
Q pagoda & $6-9$ & -21 to -4 \\
Q falcata & $6-9$ & -21 to -3 \\
Q nigra & $7-9$ & -18 to -1 \\
\hline
\end{tabular}

expected to vary with seed source in experimental plantations.

In uniform-environment provenance tests of a geographically variable species, extensive provenance sampling covering the entire distribution strengthens the provenance component of variance in relation to stand and family components, whereas range restriction leads to proportionately larger regional and local components (Kriebel. 1965). In several species of Quercus, mid-range or confined-latitude sampling indicated that, within the region studied, stand variability was more important than geographic variability, and geographic patterns were not observed (Kriebel, 1965; Houston, 1987; Schnabel and Hamrick, 1990). However, this paper demonstrates that results are very different, at least in $Q$ rubra, when samples are more widely dispersed.

Most of the information currently available on intraspecific variation in the North American oaks is based on population samples covering only parts of the species distribution. Far more information is available on $Q$ rubra than on any other species. In addition, there have been several provenance experiments on $Q$ falcata and the closely-related $Q$ pagoda. Reported results from research on $Q$ alba and $Q$ nigra are not range-wide and are limited to juvenile material. Some information is available on growth and adaptatibility of $Q$ macrocarpa from one provenance test at age 11 years. Apart from these 6 species, there is a little information in the liter- 


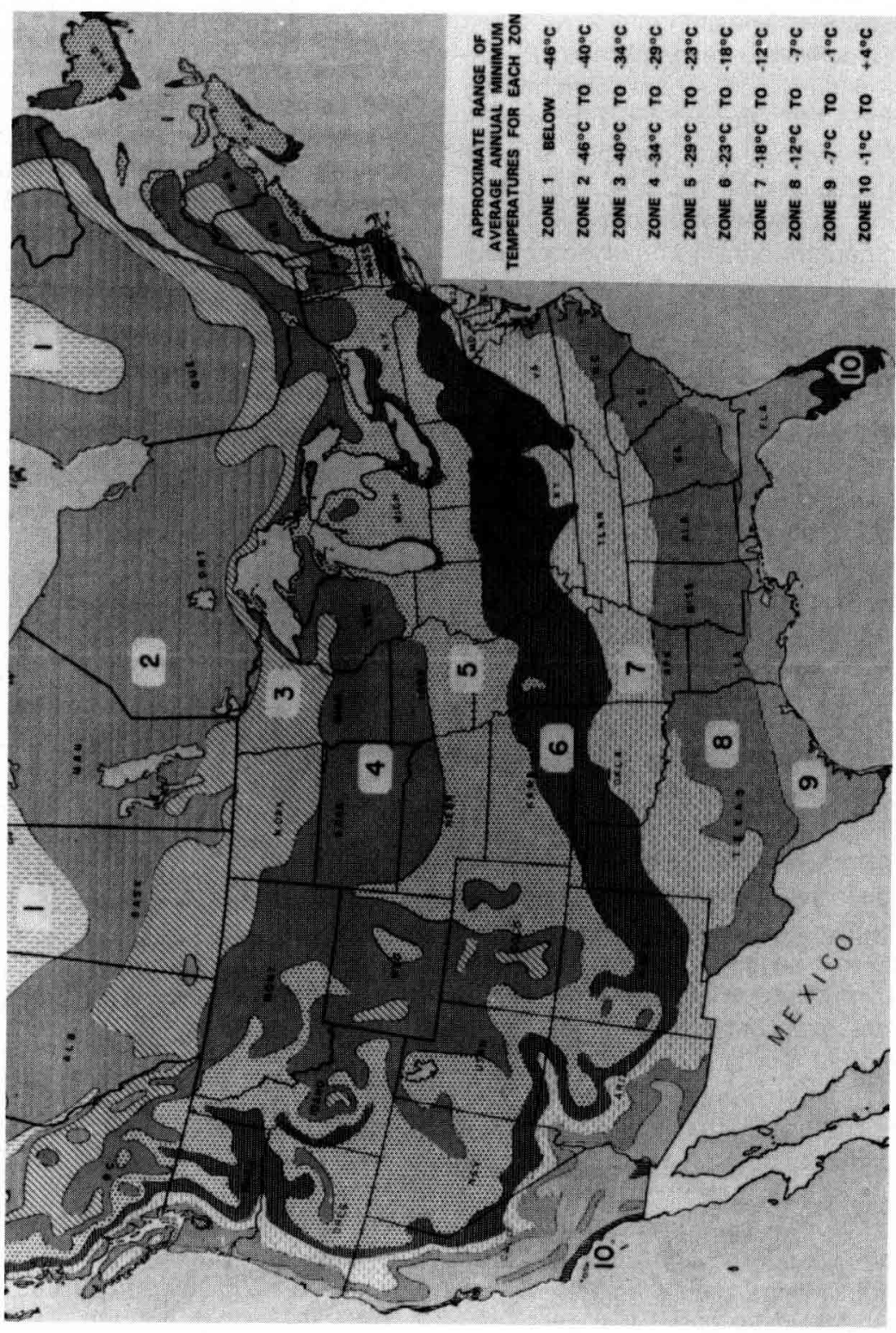


ature on variation of growth and adaptive traits in North American oaks. Brief discussions on 7 other species are included in this review. The information is taken from: 1) published research; and 2) unpublished data and reports obtained by the author. With the exception of experimental analysis of one commercially important adaptive trait in $Q$ palustris, the information on these other oaks is based on fragmentary data from limited population sampling.

\section{NORTHERN RED OAK}

About 25 provenance tests of northern red oak (Quercus rubra $L$ ) of varying size have been established in North America, but some no longer exist and others have not been evaluated. Some are comprehensive, multi-family experiments that are range-wide and replicated in several locations, while others include only a few population samples or are regional in their sampling pattern. The first $Q$ rubra provenance tests, which were established by Scott Pauley in Massachusetts in 1951 and 1952, were the most geographically comprehensive tests of this species in North America. They included 80 seed sources that sampled most of the natural distribution. Unfortunately, the plantations were not maintained and the only published report is a study of cold-hardiness. Nine replicated range-wide tests were planted in the North Central states between 1960 and 1962. Results from 7 of these have been published. The other intensive study was of more than 200 families from Tennessee and adjacent areas; of 10 outplantings, results from 3 are summarized. Additional information was available from 4 other northern red oak studies, 2 in the northeastern and 2 in the southeastern parts of the USA. A summary follows.

\section{Variation in growth rate}

Northern red oak (Quercus rubra $L$ ) varies with geographic origin in rate of height and diameter growth. The geographic pattern was evident in 23-year-old trees in 4 range-wide tests in middle latitudes of the species range from eastern Nebraska to northern Ohio (Kriebel et al, 1988), but not at age 14 years in the same tests (Kriebel et al, 1976). There was no statistical evidence of a pattern in results from limitedarea sampling (Kriebel, 1965; Farmer et al, 1981; Houston, 1987; La Farge and Lewis, 1987).

The variation pattern is as follows: height growth means are almost always highest in trees from provenances between latitudes 43 and $46^{\circ} \mathrm{N}$ in an eastwest zone extending from the Mississippi River to western Maine. Trees from outside of this zone are, on the average, slower-growing. In Ohio, Indiana and Michigan experiments, all but one of the provenance samples that exceeded the mean annual increment of its age class by more than 1 standard deviation was of Wisconsin, Michigan, Ontario, New York or Maine origin (Kriebel et al, 1988). There were indications of a similar pattern in a test of the same material in eastern Nebraska, where the fastest-growing trees were from Wisconsin and extreme eastern Minnesota (Schlarbaum and Bagley, 1981). These patterns are summarized in table II.

From these evaluations up to age 23 years, we can conclude that at latitudes $40-42^{\circ} \mathrm{N}$ in the USA significant gains in growth of northern red oak can be achieved by planting trees from seed origins $250-550 \mathrm{~km}$ north of the planting locality. In addition, since growth varies with stand and family (Kriebel et al, 1988), intraprovenance selection is important for planting in this region. 
Table II. Provenances of $Q$ rubra with mean annual height increment at age 21-23 yr (14 in Nebraska) exceeding the test mean by $>1 \mathrm{~s}$ in replicated range-wide experiments. Provenances are ranked in decreasing order of growth rate. The experiments are at $40-42^{\circ} \mathrm{N}$ locations in the USA; the database includes the 20 provenances common to all 4 locations (Schlarbaum and Bagley, 1981; Kriebel et al, 1988).

Test location

Ohio Indiana Michigan Nebraska

\begin{tabular}{llll}
\hline & W Wisconsin & N Michigan & E Minnesota \\
S Ontario & S Wisconsin & S Ontario & W Wisconsin \\
N Michigan & S Ontario & W Ohio & \\
W Wisconsin & & N New York & \\
& & W Wisconsin &
\end{tabular}

We do not know whether the same superiority of northern over southern origin trees of $Q$ rubra applies to plantations in other regions. Fragmentary but inconclusive data suggest that it might not apply in regions farther south. In a replicate of the above experiments that was planted in Kansas, tree diameter was inversely correlated with seed source latitude, ie, the southern provenances had the fastergrowing trees. However, data were taken at age 11 years, and the plantation had low survival percentages of all seed source samples (Deneke, 1975). A similar trend was noted in a progeny test in eastern Tennessee that included families from Tennessee, Virginia and Kentucky. The shortest 10 families in mean height at age 20 years were from the more northern origins (Schlarbaum, 1991). Since all the seed sources were in a narrow latitudinal range relative to the species distribution, results are not comparable with those of the range-wide tests.

\section{Variation in adaptive traits}

Northern red oak varies geographically in drought resistance. Trees from prove- nances in low rainfall regions west of the Mississippi River, near the range limits, are more drought-resistant than those of other origins. These differences were observed in a provenance test in Kansas, at the southwestern limits of $Q$ rubra, where mean summer temperature is highest and mean annual precipitation is lowest within the species range. Trees originating from this region, including lowa, Kansas and Missouri, had higher survival rates than those from any other provenance (Deneke, 1975).

Cold hardiness of northern red oak depends upon geographic origin. Twigs collected from 16- to 18-year-old trees of 38 origins growing in Massachusetts (Pauley and Johnson, 1955) were subjected to controlled freezing experiments. Cold hardiness was strongly related to estimated mean annual minimum temperature of the origin and to latitude of origin. In all cases, however, cold hardiness was greater than that required by the climate of the origin, suggesting that twig hardiness in established trees is not an important factor in natural selection under contemporary climatic conditions (Flint, 1972).

Data of bud-break or leaf flushing of northern red oak depends upon seed source; in the north central region of the 
USA, flushing begins in trees of northwestern origin, then proceeds 'eastward' through trees of northern origin to trees of northeastern origin, and also 'southward' to trees of central and southern provenance, ending in trees of mid-latitude origins from southern Michigan to Pennsylvania (Kriebel et al, 1976). This trend is not significantly correlated with latitude and it is only weakly correlated with longitude (Schlarbaum and Bagley, 1981). In eastern Tennessee, the pattern of flushing is very different: the general trend begins in trees of southern origins and ends in trees of northern origins (Gall and Taft, 1973; Schlarbaum, 1991).

Data of bud-break advances with increase in seed source elevation; in western North Carolina, the time spread between the lowest and highest elevation source was 11 days, regardless of plantation elevation (McGee, 1974).

Unlike the flushing date, the time of leaf senescence in $Q$ rubra is very strongly correlated with the latitude of the seed source, progressing clinally from north to south (Deneke, 1975; Kriebel et al, 1976; Schlarbaum and Bagley, 1981).

\section{SOUTHERN RED OAK}

Two principal studies have been conducted on geographic variation in southern red oak (Quercus falcata Michx). One comprises two 43-origin, range-wide provenance tests in the Piedmont region of western South Carolina (Schoenike et al, 1982). The other is a central Mississippi test of 112 trees from 43 stands in 23 provenances, including most of the natural distribution with the exception of Florida and areas north of $36^{\circ} \mathrm{N}$ (Mukewar and Land, 1987). In addition, a few families of 4 provenances were tested at the Michaux Quercetum in southeastern Pennsylvania (San- tamour et al, 1980), with partial replication in northern Ohio (author's records).

\section{Variation in growth rate}

Seed source had a strong effect on tree height in South Carolina at age 10 years. Southern red oaks that surpassed the local source were from the lower coastal plain of North and South Carolina, southern Mississippi, southeastern and north-central Louisiana, southeastern Arkansas and southeastern Missouri. Those growing more slowly were from Piedmont and mountainous regions of Virginia and North Carolina, Tennessee, Florida, eastern Texas, Alabama, southern Missouri and southern New Jersey. These provenances are near the periphery of the species range. No clinal trends were found, nor were there any meaningful correlations with latitude, longitude, mean annual temperature or length of growing season.

In central Mississippi, provenance effects at age 5 years accounted for about $70 \%$ of total variation, and families within stands $20 \%$. There was very little difference among stands within provenances. Southern red oaks from seed sources in southeastern Texas and eastern Georgia were significantly faster-growing than those from the other 21 provenances.

Farther north, in southeastern Pennsylvania, the comparison was made between 2 seed sources of southern red oak that are northern for the species and 2 sources in the southern part of the species range. Progenies from seeds collected in the nearby region of Maryland and Virginia outgrew those of Alabama and Arkansas origins.

\section{Variation in adaptive traits}

Survival of southern red oak in South Carolina and Mississippi is not source-related. 
In southeastern Pennsylvania, it is; trees from Mississippi suffer heavy mortality from winter temperatures. Trees of Arkansas sources are less affected, but of the 4 provenances tested, only Virginia and Maryland trees had high survival rates (Santamour et al, 1980). In Ohio, where winters are more severe, trees of the Virginia seedlot that were hardy in Pennsylvania all died within the first few years after planting. Other sources were not tested (author's records).

\section{CHERRYBARK OAK}

Harlow et al (1991) now follow Jensen (1989) in classifying cherrybark oak as Quercus pagoda Raf rather than as a form of southern red oak (Quercus falcata var pagodaefolia Ell). The 2 oaks were considered by Ware (1967) and Jensen to be sister species that are incompletely reproductively isolated. In support of species separation, Jensen stated that, "differences between them can be detected consistently in geographically widespread locales, indicating that recognition of these taxa as species is in keeping with the generally accepted species concept in oaks." $Q$ falcata characteristically occupies a xeric habitat, whereas $Q$ pagoda occurs in mesic habitats.

\section{Variation in growth rate}

Cherrybark oak has been described as the most rapidly growing southern oak (Randall, 1972). As in $Q$ falcata, the growth rate of $Q$ pagoda is very dependent upon seed source. In a western Tennessee test that included 36 phenotypic selections at age 10 years, trees from Mississippi and Arkansas seed sources grew poorly compared with those from the Tennessee sources (Overton, 1981). By age 14 years, the tallest of the Tennessee families had a mean height of $\approx 11 \mathrm{~m}, 2-6 \mathrm{~m}$ above the means of southern and western trees (University of Tennessee, unpublished data).

In a more recently initiated study near the Mississippi River in extreme northwestern Kentucky (including provenances from Louisiana, Mississippi, Alabama, Tennessee, Kentucky and Virginia), the trees from Tennessee and Mississippi were outgrowing those from other sources at age 5 years. Some were $6 \mathrm{~m}$ in height (Rousseau $R T$, unpublished data).

Farther north, in Indiana, cherrybark oaks from the northern extremity of the species range in southern Indiana were significantly taller than all others at age 7 years. The test included 9 seed sources in 6 states ( $M$ Coggeshall, unpublished analysis and these proceedings).

\section{Variation in adaptive traits}

Cherrybark oak is highly variable in cold hardiness. In western Tennessee, families of local origin averaged $92 \%$ survival at age 10 years, while those from Mississippi and Arkansas averaged $66 \%$ (Overton, 1981). In southern Indiana, Coggeshall's records show that only trees from extreme southwestern Indiana, the northernmost point in the species range, remained completely healthy after a 10-day period with a low temperature of $-31^{\circ} \mathrm{C}$. There was a high negative correlation between degree of winter injury and seed source latitude.

\section{WHITE OAK}

White oak (Quercus alba L) grows throughout the eastern United States, with the exceptions of northern Maine and the Florida peninsula. It also occurs in parts of southern Ontario and Quebec. Although it is one of the most common and commercially im- 
portant oaks in the eastern United States, there is no range-wide provenance test of the species. The most geographically dispersed set of population samples is in the Michaux Quercetum test in southwestern Pennsylvania, which includes small numbers of trees of 18 families from 9 provenances (Santamour et al, 1980). Eight of these provenances are replicated in Wooster, Ohio. There are 2 tests established by Coggeshall in southern Indiana containing 63 and 70 families from throughout Indiana. Results from an unpublished evaluation of 5-year-old in the Indiana tests sent to the author by Coggeshall are included in this review.

\section{Variation in growth rate}

No geographic pattern of variation in growth rate was evident among 24-yearold white oaks of 9 provenances in Pennsylvania. The sampling dispersion was from Massachusetts and Virginia in the east to Wisconsin and Arkansas in the west (Santamour et al, 1980). Results were the same in the Ohio replicate at age 11 years (author's data). This absence of a pattern is not surprising, considering the small number of provenances and the variation among seedlots. In southern Indiana, where 5 latitudinal transects were made, including 2 stands per transect, family differences were about 2.5 times stand differences. Stand, transect and stand-withintransect differences were not significant at either test location. Growth of trees from local stands exceeded the test mean at both test sites. These early Indiana results suggested that, in that region, some gain in growth of white oak may be obtained by using seed sources (or stands) from a latitude of up to $2^{\circ} \mathrm{N}$ of the planting site, but that extreme northern Indiana seed should be avoided for planting in southern Indiana.
There was no evidence from any of these limited-sample $Q$ alba experiments that survival rate was related to the geographic origin of the seed.

\section{BUR OAK}

Bur oak (Quercus macrocarpa Michx) has a very wide north-south natural distribution (table I), extending from Manitoba nearly to the Gulf of Mexico. It also has a wide longitudinal range, extending from New Brunswick far into the prairies. Bur oak is extremely drought-resistant (Fowells, 1965). Provenance variation has been studied in eastern Nebraska and on a smaller scale in eastern Pennsylvania and Ohio.

\section{Variation in growth rate}

In eastern Nebraska, a test of 50 seed sources sampled the species range, but population sampling was mainly concentrated in Kansas and Nebraska. Height at age 11 years was maximum in trees originating $160 \mathrm{~km}$ south of the plantation at $40^{\circ} \mathrm{N}$. There was no observed continuous geographic pattern of growth rate (Dicke and Bagley, 1980). In eastern Pennsylvania, only 2 seedlots each from Kansas, South Dakota and Minnesota were tested. Height growth tended to increase with decreasing latitude of seed origin; Kansas trees averaged about 1.5 times the height of Minnesota trees (Santamour et al, 1980).

\section{Variation in adaptive traits}

Date of leaf fall was not related to the latitude of the seed origin in Nebraska. In southeastern Pennsylvania, survival rate of bur oak by age 25 years was 4 times high- 
er among Kansas trees than among Minnesota trees. Since the test site has a milder winter climate and higher precipitation than either the Kansas or Minnesota collections, the differential survival does not appear to reflect differences in either cold hardiness or drought resistance. Bur oaks from these 2 sources had a high survival rate in northern Ohio.

\section{WATER OAK}

Water oak (Quercus nigra $\mathrm{L}$ ) is a southern, mild-climate species. At its northernmost limits, mean minimum winter temperature is -18 to $-12^{\circ} \mathrm{C}$ (US Dep Agric, 1960). Most information on geographic variation is available from one 5-year-old provenance test in central western Louisiana and from southeastern Pennsylvania.

\section{Variation in growth rate}

In Louisiana, 68 water oak families were taken from 12 sampling points in the western part of the species distribution, consisting of 3 north-south transects, one along the Mississippi River and the others 160 $\mathrm{km}$ east and west of it. At age 5 years, there was no distinct geographic pattern. Trees from the middle Mississippi River and middle eastern Mississippi sources were consistently high in both diameter and height growth, but trees of southwestern Louisiana origin, which averaged $4.2 \mathrm{~m}$ at age 5 years, were superior overall in rate of height growth independent of diameter (Adams, 1989).

\section{Variation in adaptative traits}

$Q$ nigra trees of northern Arkansas origin flushed 7-10 days later in Louisiana than trees of more northern origin. A late frost damaged foliage of local and southern provenance material, but there was no injury to the Arkansas trees (Adams, 1989). In southeastern Pennsylvania, near the northern range limits, survival of trees of Virginia provenance was highest, averaging $76 \%$. Survival of Maryland and Mississippi trees was lower (Santamour et al, 1980). Only 3 trees from one source (Virginia) were tested in northern Ohio, a colder climate than southeastern Pennsylvania. Records show that all 3 were growing at age 11 years.

\section{OTHER NORTH AMERICAN OAKS}

With the exception of one study of Quercus palustris Muenchh, information on variation of growth and adaptive traits in other oaks is based on the testing of openpollinated progenies at the Michaux Quercetum, Longwood Gardens, PA. Seed samples from various North American oaks were collected from a small number of trees in each of 2-9 geographically dispersed localities. Trees from each seedlot were divided into 2 row-plot replicates; the total number of trees planted per seedlot varied from 11 to 42 . Analysis of juvenile material indicated that there was genetic variation in growth and phenology, but no geographic patterns could be identified (Gabriel, 1958; Santamour and Schreiner, 1961; Schreiner and Santamour, 1961). An assessment of growth and survival of all oak collections in the Quercetum was made at age 25 years (Santamour et al, 1980). Three-tree plots of many of the Quercetum collections were planted by Kriebel at Wooster, Ohio and measured at age 11 years. The data were not published and a large part of the test was subsequently lost due to road construction. Given the limitations of these experiments, the results nevertheless report the perfor- 
mance of source-documented trees and provide some useful information on growth and climatic adaptability in relation to provenance.

\section{Pin oak}

Experiments with pin oak (Quercus palustris Muenchh) on 19 natural and 2 cultivated populations well-distributed throughout the natural distribution were designed and carried out to evaluate the severity of iron chlorosis in solution culture and soil environments. There were significant differences in resistance among the progenies of different pin oak parents, but the rankings varied considerably among experimental environments. There was some indication of a geographic pattern; population samples from northcentral and northwestern parts of the species range (Indiana, Illinois, Missouri) were consistently among the most resistant populations. One population from northern Illinois was a particularly promising candidate for testing and selection (Berrang and Steiner, 1980).

\section{Shumard oak}

In Pennsylvania, the growth rate of Shumard oak (Quercus shumardii Buckl) was higher in trees of Mississippi provenance than in trees from Illinois, Tennessee and Florida sources. Juvenile trees of all sources except Illinois had an extended growing season and were killed back by early fall frosts. However, at age 25 years, the $70 \%$ survival rate of Shumard oaks of Mississippi origin was nearly as high as that of Illinois trees and growth rate was higher, up to $17.1 \mathrm{~m}$. In the colder climate of northern Ohio, the Mississippi and Florida collections were not winter-hardy. Trees of Illinois origin were $17 \%$ taller on the average than trees from the Tennessee provenance.

\section{Black oak}

There are 11 seedlots of 6 provenances of black oak (Quercus velutina Lam), in the 25-year data from Pennsylvania. Seed origins include Alabama, Tennessee, North Carolina, Virginia, Illinois and Michigan. The Ohio collections originally included 8 $Q$ velutina seedlots from the same provenances and Connecticut. In southeastern Pennsylvania, seedlot differences in 25year height growth within provenances were small. Although black oaks of Tennessee and Illinois origins were slightly faster-growing than others, averaging $16.3 \mathrm{~m}$, North Carolina trees had the highest survival rate. In northern Ohio, the mean height of one Michigan family was $30 \%$ greater than the mean of 2 Tennessee families. Black oaks of Alabama origin were not winter-hardy in Ohio and there was dieback of Virginia and North Carolina trees.

\section{Scarlet oak}

The Michaux Quercetum plantings include 4 provenances of scarlet oak (Quercus coccinea Muenchh) in Pennsylvania and 3 in Ohio. In Pennsylvania, trees from Tennessee and Illinois seedlots had a mean height at age 25 years of $15.5 \mathrm{~m}$, a slight superiority over the growth of Virginia and Alabama trees. Survival differences were not source-related. Of the 3 provenances represented in Ohio, trees from the one Virginia provenance were $36 \%$ fastergrowing at age 11 years than the mean of 2 Tennesee provenances. Scarlet oaks from Alabama seedlots did not survive in Ohio. 


\section{Willow oak}

Six seedlots of 4 provenances of willow oak (Quercus phellos L) were tested in Pennsylvania. The provenances were Mississippi, Arkansas, Virginia and Maryland. Willow oaks of Virginia origin were tallest with a mean height of nearly $16 \mathrm{~m}$ at age 25 years, but only one-third of the trees survived the winters. The survival rate of trees in the Arkansas collections was about twice that of the others. Only Arkansas trees were winter-hardy in Ohio, but growth was slow, averaging $1.5 \mathrm{~m}$ at age 11 years.

\section{Shingle oak}

Shingle oak (Quercus imbricaria Michx) was represented in both Pennsylvania and Ohio by 3 sources (Illinois, Indiana and Ohio). There were no clear source-related differences in growth rate or hardiness in either location. At age 25 years in Pennsylvania, trees of Indiana origin averaged $15.6 \mathrm{~m}$ in height and were taller than those from Illinois and Ohio.

\section{Blackjack oak}

One progeny of each of 4 provenances of blackjack oak (Quercus marilandica Muenchh) was tested in southeastern Pennsylvania. The provenances were in Texas, Kansas, Arkansas and New Jersey. Height growth in 25 years varied from a mean of $9.4 \mathrm{~m}$ for trees of Texas origin to $7.2 \mathrm{~m}$ for trees from the New Jersey seed source. The survival rate of blackjack oak varied from $10 \%$ in the Texas progeny to $38 \%$ in the progeny from nearby southern New Jersey.

\section{CONCLUSIONS}

With the exception of results from tests of Quercus rubra, information on variation in growth and adaptive traits of the North American oaks is still very limited. Even $Q$ rubra is inadequately sampled, considering its abundance and wide distribution. The distribution of $Q$ falcata has been more completely sampled than has that of the wider-ranging $Q$ rubra, although the future of the South Carolina tests of southern red oak is uncertain. However, some useful information is now available about intraspecific variation in growth rate and winter hardiness in this species. Studies of variation in $Q$ pagoda are yielding valuable information, but they do not cover the entire species range. Considering the economic importance of $Q$ alba, we should be much farther ahead than we are in our research on this species. Our white oak tests are very limited, both geographically and in sampling intensity. Because of its drought-resistance in the prairie regions of North America, $Q$ macrocarpa merits further research on vigor and hardiness. The recently initiated effort under way with $Q$ nigra, focusing on the western part of the species range, will provide some information on this previously untested fast-growing species. Tests of scattered seed sources of 6 other oaks provide fragments of information thay may reduce the risk of plantation failure and increase productivity in certain regions, although they are at best only indicative and in no case descriptive of variation of the species as a whole. Indications of variation in resistance to iron chlorosis in $Q$ palustris may be useful in urban forestry. As far as other North American oaks are concerned, including the western species, their intraspecific variation is virtually unknown. 


\section{REFERENCES}

Adams JC (1989) Five-year growth results of water oak (Quercus nigra $L$ ) provenances. Proc South For Tree Improv Conf 20, 310314

Berrang P, Steiner KC (1980) Resistance of pin oak progenies to iron chlorosis. J Am SoC Hortic Sci 105, 519-522

Deneke FJ (1975) A red oak provenance trial in Kansas. Trans Kans Acad Sci 77, 195-199

Dicke StG, Bagley WT (1980) Variability of Quercus macrocarpa Michx in an eastern Nebraska provenance study. Silvae Genet 29, 171-176

Farmer RE, Jr, Barnhill MA, Rennie JC (1981) Variation in 10-year growth of northern red oak from provenances in the Tennessee Valley. Proc North Central Tree Improv Conf 2 , 100-105

Flint HL (1972) Cold hardiness of twigs of Quercus rubra $L$ as a function of geographic origin. Ecology 53, 1163-1170

Fowells HA (1965) Silvics of Forest Trees of the United States. US For Serv Agric Handb, 271

Gabriel WJ (1958) Genetic differences in juvenile Shumard oak. US For Serv Res Note NE $81,3 p$

Gall WR, Taft KA, Jr (1973) Variation in height growth and flushing of northern red oak (Quercus rubra L). Proc South For Tree $\mathrm{Im}$ prov Conf 12, 190-198

Harlow WM, Harrar ES, Hardin JW, White FM (1991) Texbook of Dendrology. 7th edn McGraw-Hill, New York,

Houston DB (1987) Variation in southern seed sources of northern red oak. Proc North Central Tree Improv Conf 5, 132-140

Jensen RJ (1989) The Quercus falcata Michx complex in Land Between The Lakes, Kentucky and Tennessee: a study of morphological variation. Am Midl Nat 121, 245-255

Kriebel HB (1965) Parental and provenance effects on growth of red oak seedlings. Proc Central States For Tree Improv Conf 4, 1925

Kriebel HB, Bagley WT, Deneke FJ, Funsch RW, Roth P, Jokela JJ, Merritt C, Wright JW, Williams RD (1976) Geographic variation in
Quercus rubra in north central United States plantations. Silvae Genet 25, 118-122

Kriebel HB, Merritt C, Stadt T (1988) Genetics of growth rate in Quercus rubra: provenance and family effects by the early third decade in the north central USA. Silvae Genet 37, $193-$ 198

La Farge T, Lewis RA (1987) Phenotypic selection effective in a northern red oak seedling seed orchard. Proc South For Tree Improv Conf 19, 200-207

McGee CE (1974) Elevation of seed sources and planting sites affects phenology and development of red oak seedlings. For $\mathrm{Sci} 20$, 160-164

Mukewar AM, Land SB Jr (1987) Geographic genetic variation in southern red oak. Proc South For Tree Improv Conf 19, 415-422

Overton RP (1981) Genetic Improvement of Cherrybark Oak: A Cooperative Project. US For Serv South For Exp Stn, Prog Rep FSSO-1402-1.6

Pauley SS, Johnson AG (1955) Plantations Established During the Period 1947-1955. Harvard Univ, Maria Moors Cabot Found Bot Res

Randall WK (1972) Genetic Improvement of Cherrybark Oak: A Cooperative Project. US For Serv South For Exp Stn, Prog Rep FSSO-1110-5.7

Santamour FS, Schreiner EJ (1961) Juvenile variation in five white oak species. Morris Arbor Bull 12, 37-46

Santamour FS, Garrett PW, Paterson DB (1980) Oak provenance research: the Michaux Quercetum after 25 years. J Arboric 6, 156160

Schlarbaum SE (1991) Detection of Variation in Leaf Flush, Flowering, Growth and Acron Production in a Quercus Rubra Seedling Seed Orchard. Univ Tennessee Prog Rep to US For Serv, Agreement No 19-90-035

Schlarbaum SE, Bagley WT (1981) Intraspecific genetic variation of Quercus rubra L, northern red oak. Silvae Genet 30, 50-56

Schnabel A, Hamrick JL (1990) Comparative analysis of population genetic structure in Quercus macrocarpa and $Q$ gambelii (Fagaceae). Syst Bot 15, 240-251

Schoenike RE, Benson JD, Astriab TA (1982) Ten year growth of froty-three seed sources of southern red oak (Quercus falcata Michx) 
in two Piedmont South Carolina plantations. Clemson Univ Dep For For Bull 33

Schreiner EJ, Santamour FS Jr (1961) Juvenile variation in five red oak species. Morris Arbor Bull 12, 65-70
US Dep Agric (1960) Plant Hardiness Zone Map. US Dep Agric Misc Publ 814

Ware $S$ (1967) The morphological varieties of southern red oak. J Tenn Acad Sci 42, 2936 